\title{
Fallittforetak i konkurranseretten
}

\author{
Prof. Erling Hjelmeng, UiO og prof. Eirik Østerud, UiO
}

Fallittforetak, det vil si foretak som trer ut av et marked på grunn av akutte $\emptyset$ konomiske vanskeligheter, reiser en rekke konkurranserettslige spørsmål. I artikkelen problematiseres blant annet anvendelsen av foretakssammenslutningsbegrepet på erverv av aktiva fra konkursbo, praktiseringen av gjennomføringsforbudet og tilhørende dispensasjoner i saker om fallittforetak, inngrepsvurderingen for foretakssammenslutninger og fallittforetaksforsvaret, krisekarteller, samt allokering av bøteansvar og erstatningsansvar der fallittforetak har overtrådt konkurranserettens atferdsforbud.

Nøkkelord: Fallittforetak, foretakssammenslutning, krisekartell, konkurranserett, konkurs.

\section{Innledning}

Såkalte fallittforetak («failing firms») er opphav til en rekke konkurranserettslige problemstillinger. Betegnelsen «fallittforetak» har ingen klar rettslig definisjon, men viser til foretak som sannsynlig vil forlate eller har forlatt et marked på grunn av økonomiske vanskeligheter, eksempelvis ved en konkurs.

I artikkelen diskuteres ulike problemstillinger om tolkingen og anvendelsen av norsk konkurranserett relatert til fallittforetak. Med norsk konkurranserett menes de generelle rettsreglene som skal hindre foretak fra å begrense konkurranse på markeder for utveksling av varer og tjenester. Reglene finner vi i konkurranseloven (krrl.) ${ }^{1}$ og i EØS-avtalen ${ }^{2}$. Problemstillingene gjelder både reglene om foretakssammenslutninger, konkurranseskadelig atferd, sanksjoner og erstatningsansvar.

Tematikkens aktualitet er forsterket av de økonomiske konsekvensene utløst av koronaviruset (COVID-19) våren 2020. Det er ventet en sterk økning i antallet konkurser. I en medlemsunders $\varnothing$ kelse fra $\mathrm{NHO}$ av 23. mars 2020 rapporterte $1 / 3$ av respondentene om reell risiko for konkurs. ${ }^{3}$

I det følgende drøfter vi et utvalg krysningspunkter mellom konkurransereglene og fallittforetak. Først ser vi på tolkingen og anvendelsen av foretakssammenslutningsbegrepet på fallittforetak, jf. del 2. Deretter diskuterer vi forholdet mellom gjennomføringsforbudet, med unntak, og fallittforetak, jf. del 3. I del 4 drøftes anvendelsen av inngrepsvurderingen for foretakssammenslutninger på fallittforetak. Forbudet mot konkurransebegrensende samarbeid og såkalte krisekarteller behandles i del 5. Til slutt, i del 6 og 7, problematiserer vi konkurransereglene om henholdsvis bøteansvar og erstatningsansvar og fallittforetak.

\footnotetext{
${ }^{1}$ Lov 5. mars 2004 nr. 12 om konkurranse mellom foretak og kontroll med foretakssammenslutninger.

${ }^{2}$ Avtale om Det europeiske økonomiske samarbeidsområde. Lov 27. november 1992 nr. 109 om gjennomføring i norsk rett av hoveddelen i avtale om Det europeiske økonomiske samarbeidsområde (EØS) m.v.

${ }^{3}$ www.nho.no/tema/arbeidsliv/koronaviruset/1-av-3-frykter-konkurs---et-vare-eller-ikke-vare/
} 


\section{Foretakssammenslutningsbegrepet og fallittforetak}

Begrepet «foretakssammenslutning» angir gjenstanden for konkurranselovens og den felleseuropeiske konkurranserettens regler om forhåndskontroll med blant annet foretakssammenslutninger. ${ }^{4}$ Begrepet har følgelig betydning for reglene om blant annet meldeplikt, gjennomføringsforbud, inngrep og håndheving.

Foretakssammenslutningsbegrepet omfatter varige strukturendringer, i form av fusjoner, kontrollovertakelser av andre foretak og opprettelser av selvstendig fungerende fellesforetak, jf. krrl. § 17. En foretakssammenslutning er en varig konsolidering av selvstendige foretak. Av praksis fra EUdomstolen (Retten) følger at «concentrations have the following characteristics in common: where before the operation there were two distinct undertakings for a given economic activity, there will only be one after it». ${ }^{5}$ Foretaksbegrepet er følgelig styrende for foretakssammenslutningsbegrepet. Foretaksbegrepet er konkurranserettslig autonomt, funksjonelt og ikke knyttet til særskilte juridiske personer. ${ }^{6}$ Det avgjørende er ut $\varnothing$ velse av $\varnothing$ konomisk virksomhet, ${ }^{7}$ det vil si tilbud av varer eller tjenester i et marked. ${ }^{8}$ Et foretak defineres som en $\varnothing$ konomisk enhet og kan bestå av flere juridiske og fysiske personer. ${ }^{9}$ Avgrensningen beror på om en virksomhet er underlagt en annens avgjørende innflytelsesmulighet (kontroll), eller om virksomhetene er strategisk autonome. ${ }^{10}$

Vedrørende fallittforetak kan det spørres om opprettelsen av et konkursbo utgjør en foretakssammenslutning. Svaret er imidlertid entydig negativt, jf. fusjonskontrollforordningen ${ }^{11}$ $(« \mathrm{FKF} »)$ art. 3(5)(b). Konkurranselovens foretakssammenslutningsbegrep er harmonisert med FKFs, selv om presiseringen i art. 3(5)(b) ikke er inntatt i loven. Konkursbehandling vil uansett ikke utgjøre noen «varig» kontrollendring.

Mer problematisk kan være under hvilke omstendigheter realisering av boets eiendeler utgjør en foretakssammenslutning. For at realiseringen av hele eller deler av boet skal kvalifisere til en foretakssammenslutning må erverver være et «foretak», det vil si en enhet som driver $\emptyset$ konomisk virksomhet. Videre må også objektet for kontrollendringen være et «foretak» i konkurranserettslig forstand. Transaksjonsgjenstanden må med andre ord være en autonom økonomisk enhet, og overføringen må derfor omfatte de nødvendige eiendeler og funksjoner til at virksomheten kan operere selvstendig. ${ }^{12}$ Hva som er nødvendig vil variere beroende på virksomhetens art og de konkrete varene eller tjenestene foretaket tilbyr. Nødvendige indre eiendeler og funksjoner kan innbefatte en ledelse, ansatte, samt produksjonsmidler, materielle og immaterielle eiendeler. Nødvendige ytre funksjoner fordrer at transaksjonsobjektet har selvstendig tilstedeværelse i markedet, og ikke kun har utført interne støttefunksjoner i et større foretak.

Erverv av begrensede aktiva som ikke utgjør noe konkurranserettslig «foretak», er heller ikke en foretakssammenslutning. EU-domstolen benytter i så måte «foretak» til å angi transaksjonsobjektet i en foretakssammenslutning, og har forklart at en foretakssammenslutning gjennomføres der foretakene «implement operations contributing to a lasting change in the control of the target undertaking». ${ }^{13}$ For

\footnotetext{
${ }^{4}$ På grunn av COVID-19 ble 7. april 2020 vedtatt midlertidig lov om unntak fra konkurranselovens prosessuelle regler som blant annet forlenger tidsfristene ved kontroll med foretakssammenslutninger. Loven gjelder til 31. oktober 2020.

${ }^{5}$ Sak T-411/07, Aer Lingus, ECLI:EU:T:2010:281, avsn. 63.

${ }^{6}$ Krrl. $\$ 2$.

${ }^{7}$ Sak C-41/90, Höfner, ECLI:EU:C:1991:161, avsn. 21 og krrl. § 2.

${ }^{8}$ Sak C-205/03, FENIN, ECLI:EU:C:2006:453, avsn. 25.

${ }^{9}$ Sak 170/83, Hydrotherm, ECLI:EU:C:1984:271, avsn. 11.

${ }^{10}$ Sak C-73/95, Viho Europe, ECLI:EU:C:1996:405, avsn. 16.

${ }^{11}$ Reg. 139/2004.

${ }^{12}$ Se og Generaladvokat Kokotts forslag i sak C-248/16, Austria Asphalt, ECLI:EU:C:2017:322, avsn. 33

${ }^{13}$ Sak C-10/18, Mowi, ECLI:EU:C:2020:149, avsn. 50. (uthv. her) Se og sak C-633/16, EY,

ECLI:EU:C:2018:371, avsn. 46 og 59.
} 
$\emptyset$ vrig kan anvendelsen av begrepet «foretaksammenslutning» vanskelig gi ulikt utfall beroende på hvem av de involverte som overtar kontrollen. Erverv av enkeltvise eller separate deler fra et konkursbo, så som restlager, immaterielle rettigheter, produksjonsmidler eller lokaler e.l., utgjør følgelig ingen foretakssammenslutning. Det skal likevel sies at konkurransemyndighetene undertiden har tillagt foretakssammenslutningsbegrepet større rekkevidde enn foretaksbegrepet tilsier. ${ }^{14}$

Enkelte avgjørelser fra EU-kommisjonen kan eksemplifisere foretakssammenslutningsregelverkets anvendelse på erverv av aktiva. I Blokker - Toys $R$ Us kom EU-kommisjonen til at transaksjonen kvalifiserte til en foretakssammenslutning. Begrunnelsen var at «Blokker takes over all the assets (leases, fixtures and inventory, personnel, use of brand name) which make up the business of Toys $\mathrm{R}$ Us (...). To this business, a turnover can clearly be attributed.» ${ }^{15}$ At Blokker inngikk en franchiseavtale med Toys R Us var ikke til hinder for at det var tale om en foretakssammenslutning, da avtalen ikke innebar at Toys R Us ville beholde kontrollen over virksomheten. ${ }^{16}$ Et annet eksempel er Flextronics - Certain Assets belonging to Motorola Mobility ${ }^{17}$ som gjaldt erverv av Motorolas produksjonsmidler for mobiltelefoner og nettbrett i Kina og Brasil. EU-kommisjonen mente at det var tale om en foretakssammenslutning fordi «the Motorola Assets, on a standalone basis (and therefore regardless of Flextronics' existing activities, which may complement them post-transaction) include the necessary elements to supply third parties». ${ }^{18}$ Avgjørende var at de ervervede aktivaene omfattet det nødvendige for å drive økonomisk virksomhet.

Til sammenlikning kan det vises til Konkurransetilsynets vedtak i Katalysator/Norfolier GreentecNorfolier AS konkursbo \& Norfolier Norge AS konkursbo. Tilsynet mente at det ikke var nødvendig at overførte aktiva, isolert sett, var tilstrekkelig til å igangsette produksjonen. ${ }^{19}$ Det avgjørende var «at de nevnte eiendeler og rettigheter var nært knyttet til og sentrale for de konkursslåtte selskapenes produksjons- og salgsvirksomhet, og at de til de overførte aktiva derfor må anses å være tilknyttet en klar og påviselig omsetning.» ${ }^{20}$ Etter tilsynets praksis, som ikke baseres på foretaksbegrepet, kan også alminnelige samarbeid om underleveranser kvalifisere som foretakssammenslutninger. ${ }^{21}$ En slik praktisering kan være til hinder for tilsynets anvendelse av forbudene mot konkurranserettslig atferd på blant annet prosjektsamarbeid. Avklaringshensyn tilsier at heller ikke atferdsreglene kan anvendes på foretakssammenslutninger der tilsynets frist for pålegg av melding har utløpt, jf. krrl. § 18.

Et annet eksempel fra EU-kommisjonen er Netto - Grocery Store at Armitage avenue. ${ }^{22}$ Saken gjaldt en dagligvarekjedes erverv av eiendom der det tidligere hadde vært drevet dagligvarevirksomhet. EUkommisjonen forklarte at «The Transaction concerns the acquisition of the freehold property of the Target Store. (...) This freehold property will be transferred empty, as it was stripped of all its previously installed fixtures and fittings. The Transaction does not involve the transfer of any other tangible or intangible assets.» ${ }^{23}$ EU-kommisjonen kom til at det ikke var tale om noen foretakssammenslutning, og uttalte blant annet at «the Transaction should be viewed, in essence, as a real estate transaction consisting in the acquisition of an empty freehold property, rather than as the transfer of a business with a market presence to which a turnover can be attributed.» ${ }^{24}$

\footnotetext{
${ }^{14}$ Se til eksempel EU-kommisjonens jurisdiksjonsmeddelelse, avsn. 24-27 og Konkurransetilsynets veiledning om næringseiendom, 7. september 2005.

${ }^{15}$ Sak IV/M.890, avsn. 15.

${ }^{16}$ Ibid, avsn. 15.

${ }^{17}$ Sak COMP/M.6853.

${ }^{18}$ Ibid, avsn. 11.

${ }^{19}$ V2014-12, avsn. 61.

${ }^{20}$ Ibid, avsn. 62.

${ }^{21}$ Se V2019-21 Nor Tekstil - Storvask.

${ }^{22}$ Sak M.7940.

${ }^{23}$ Ibid, avsn. 8.

${ }^{24}$ Ibid, avsn. 16.
} 
Fra norsk praksis kan her trekkes frem Norgesgruppen. Konkurransetilsynet ila dagligvarekjeden et overtredelsesgebyr på NOK 25 millioner for brudd på gjennomføringsforbudet i krrl. § 19.

Norgesgruppen hadde blant annet overtatt leiekontrakter til butikklokaler der ICA Maxi tidligere hadde drevet supermarkeder. Tilsynet vektla blant annet at «Norgesgruppen åpnet dagligvarevirksomhet i lokaler der Ica Norge kort tid tidligere drev dagligvarevirksomhet. Verken for kunder eller konkurrenter har disse dagligvarelokalene blitt trukket ut av markedet. Måten transaksjonen er strukturert på har således bidratt til å opprettholde kontinuiteten i

dagligvaredriften.» ${ }^{25}$ Snarere enn å vurdere om aktivaene utgjorde et «foretak», var tilsynets grunngiving basert på en kontinuitetsbetraktning om at Norgesgruppen i realiteten videreførte virksomheten ICA hadde drevet fra lokalene.

\section{Gjennomføringsforbudet og fallittforetak}

Meldepliktige og meldte foretakssammenslutninger må ikke gjennomføres før Konkurransetilsynet har avsluttet behandlingen av saken, jf. krrl. § 19 første ledd. Bestemmelsen er harmonisert med FKF art. $7(1) .^{26}$

Etter EU-domstolens praksis rammer gjennomføringsforbudet etableringen av en ny $\varnothing$ konomisk enhet, men ikke atferdsmessige forberedelseshandlinger. ${ }^{27} \mathrm{EU}$-domstolen har blant annet understreket at «a concentration is implemented only by a transaction which, in whole or in part, in fact or in law, contributes to the change in control of the target undertaking». ${ }^{28}$ Gjennomf $ø$ ringsforbudet kommer derimot ikke til anvendelse så lenge foretakene forblir separate. ${ }^{29}$ Samordning mellom separate foretak reguleres i stedet av forbudet mot konkurranseskadelig samarbeid.

Konkurransetilsynet har likevel tolket og anvendt gjennomføringsforbudet i krrl. § 19 som et mer vidtgående atferdsforbud. Til eksempel kan også her vises til tilsynets vedtak Katalysator/Norfolier Greentec - Norfolier AS konkursbo \& Norfolier Norge AS konkursbo. I vedtaket heter det blant annet at «[o]rdlyden i krrl. § 19 'må ikke gjennomføres' tilsier at ethvert uttalte gjennomføringstiltak er omfattet» ${ }^{30}$, «enhver overføring av aktiva, immaterialrettigheter og knowhow normalt rammes av gjennomføringsforbudet ${ }^{31}$, og videre at «[t]ypiske gjennomføringstiltak som rammes av gjennomføringsforbudet er utveksling av ytelser, fysisk integrasjon, informasjonsutveksling utover det som er legitimt og påkrevd som ledd i transaksjonen, overføring av driftsmessig kontroll og driftseller markedsmessig samordning». ${ }^{32}$ Foruten å utydeliggjøre gjennomføringsforbudets virkeområde, vilkår, rasjonale og vurderingstema, er formuleringene ikke forenelige med harmoniseringsformålet bak krrl. § 19 og EU-domstolens praksis.

Unntak fra gjennomføringsforbudet kan være aktuelt for erverv av fallittforetak fra konkursbo. Av krrl. § 19 annet ledd første punktum følger at Konkurransetilsynet etter søknad kan gjøre unntak i enkeltsaker. I forarbeidene uttalte departementet at det bare vil være aktuelt å oppheve forbudet når det

\footnotetext{
${ }^{25}$ V2014-3, avsn. 100.

${ }^{26}$ Ot.prp. nr. 6 (2003-2004), s. 232. Etter søknad kan tilsynet gjøre unntak fra forbudet i enkeltsaker, jf. § 19 annet ledd, mens EU-kommisjonens dispensasjonsadgang er hjemlet i FKF art. 7 (3). Det er gjort unntak for visse typer erverv av verdipapirer, jf. forskrift om delvis unntak fra gjennomføringsforbudet i krrl. § 19 første ledd for visse typer erverv av verdipapirer av 9. mars $2009 \mathrm{nr} .292 \mathrm{og}$ FKF art. 7(2).

${ }^{27}$ Sak C-84/13, Electrabel, ECLI:EU:C:2014:2040, sak C-633/16, Ernst \& Young, ECLI:EU:C:2018:371, sak C10/18, Mowi, ECLI:EU:C:2020:149.

${ }^{28}$ Sak C-633/16, Ernst \& Young, ECLI:EU:C:2018:371, avsn. 59.

${ }^{29}$ Ibid, avsn. 61.

${ }^{30}$ V2014-12, avsn. 76.

${ }^{31}$ Ibid, avsn. 77.

${ }^{32}$ Ibid, avsn. 77. Formuleringene er bl.a. gjentatt i V2014-15 der forbudet ble funnet overtrådt i tilknytning til foretakssammenslutningen mellom Jotunfjell Partners og Fyllingsdalen Foto Konkursbo. Vedtaket ble opprettholdt av Oslo tingrett, jf. TOSLO-2015-92069.
} 
kan påvises «alvorlige konsekvenser for partene eller for samfunnet for $\varnothing$ vrig». ${ }^{33}$ Videre vises det til at EU-kommisjonens praksis kan tjene som retningslinje for når tilsynet kan oppheve gjennomføringsforbudet. ${ }^{34}$

Konkurransetilsynet har per mars 2020 fattet 43 avgjørelser ${ }^{35}$ om unntak eller opphevelse av gjennomføringsforbudet. ${ }^{36} \mathrm{Av}$ disse gjelder et overveldende flertall (39) overtakelse av virksomhet fra konkursbo eller foretak med alvorlige økonomiske problemer, der unntak/opphevelse ble funnet nødvendig for å sikre videre drift.

Samtlige avgjørelser gjelder det tilsynet betegner som «delvis» unntak fra eller opphevelse av forbudet. Avgjørelsene går derfor typisk ut på at forbudet ikke er til hinder for at erverver overtar målvirksomheten. I tillegg tilføyer tilsynet nær konsekvent at «Utover unntak som nevnt (...) gjelder gjennomføringsforbudet fullt ut. Overtredelse av gjennomføringsforbudet kan medføre overtredelsesgebyr og straff». Også tilsynets nyeste avgjørelser er slike «delvise» unntak. $^{37}$

Konkurransetilsynets «delvishet» synes å grunne i en oppfatning av forbudet som noe annet, eller noe mer, enn et forbud mot implementeringen av foretakssammenslutningen. De «delvise» unntakene kan derfor formentlig forklares med tilsynets uriktige tolking og anvendelse av gjennomføringsforbudet som et vidtgående atferdsforbud. Når tilsynet har gitt unntak for implementeringen, er det imidlertid ikke noen «rest» eller «gjenværende del» av forbudet som kan overtres. Tilføyelser om at «Utover unntak som nevnt gjelder gjennomføringsforbudet fullt ut» uttrykker dessuten en videre oppfatning av forbudets rekkevidde enn det er rettslig grunnlag for. Påpekinger av gjennomføringsforbudets angivelige betydning ved pålegg om melding av allerede gjennomførte foretakssammenslutninger, er tilsvarende lite håndgripelige. ${ }^{38}$ For $\emptyset$ vrig har tilsynet fattet unntaksavgjørelser om atferd som uansett ikke rammes av forbudet. ${ }^{39}$

For å motvirke uønsket integrasjon der det er hensiktsmessig med dispensasjon fra forbudet, har EUkommisjonen uttrykkelig hjemmel til å stille vilkår, jf. FKF art. 7(3). Ubetingede unntak fra gjennomføringsforbudet kan risikere konkurranseskadelige eller irreversible tiltak, før det er avklart om det foreligger inngrepsgrunnlag. Mot slikt er gjennomføringsforbudet uanvendelig da forbudet kun rammer selve implementeringen av foretakssammenslutningen (kontrollendringen). Forbudet mot konkurransebegrensende samarbeid er heller ikke anvendelig etter at foretakssammenslutningen er gjennomført, da det ikke lenger foreligger separate foretak. Vilkårsadgangen etter FKF art. 7(3) kan derimot forhindre uønsket og unødig integrasjon ved dispensasjoner.

Krrl. § 19 annet ledd regulerer motsetningsvis ikke tilsynets adgang til å stille vilkår. Etter alminnelig ulovfestet forvaltningsrett kan tilsynet likevel sette saklig begrunnede og ikke uforholdsmessig tyngende vilkår. ${ }^{40}$ I Gjelsten Holding/O.N. Sunde - Gresvig Retail Group mfl. stilte tilsynet i så måte vilkår om videre drift av overtatte eiendeler i en separat juridisk enhet. ${ }^{41}$ En tilsvarende skranke

\footnotetext{
${ }^{33}$ Ot.prp. nr. 6 (2003-2004), s. 98. Se for $\emptyset$ vrig Prop. 75 L (2012-2013), s. 148.

${ }^{34}$ Ot.prp. nr. 6 (2003-2004), s. 98.

${ }^{35}$ Forvaltningsrettslige enkeltvedtak.

${ }^{36}$ https://konkurransetilsynet.no/vedtak-og uttalelser/?cat=524\&years\&paragraf1=krrl\%C2\% A719\&paragraf2\&submit=Filtrer\#038;years=\&paragraf1=krrl\$19\&paragraf2=\&submit=Filtrer

${ }^{37}$ A2020-1 Gjelsten Holding/O.N. Sunde - Gresvig Retail Group mfl., A2019-1 Jotunfjell Partners - Vita og

Loco-konsernet, A2019-2 JFP Retail Drift - Notabene, A2018-2 Coast Seafood - Roadfeeders, A2018-1

Fabritius Gruppen - A Bygg Gruppen.

${ }^{38}$ Se V2014-4 Cappelen - Kongsberg Esco, og V2020-14 Amedia Start Up - Nu Publishing, V2020-16

Schibsted - Nettbil.

${ }^{39}$ A2012-17 Simonsen Advokatfirma - Advokatfirmaet Vogt \& Wiig. Et liknende tilfelle med annet grunnlag, er V2015-26 Coop - Ica.

${ }^{40}$ Se Rt. 2003 s. 764.

${ }^{41}$ A2020-1.
} 
oppnås ikke med en avgjørelse om «delvis» unntak, der det uspesifisert heter at utover kontrollovertakelsen «gjelder gjennomføringsforbudet fullt ut».

\section{Inngrepsvurderingen og fallittforetak}

\subsection{Kravet om årsakssammenheng og kontrafaktisk scenario}

Inngrepsbestemmelsen i krrl. § 16 første ledd første punktum lyder: «Konkurransetilsynet skal forby foretakssammenslutninger som i betydelig grad vil hindre effektiv konkurranse, særlig som et resultat av at en dominerende stilling skapes eller styrkes.» Bestemmelsen ble endret med virkning 1. juli 2016, og den fikk da tilsvarende formulering som den såkalte SIEC-standarden (Significant Impediment of Effective Competition) i EU-/EØS-rettens fusjonsforordning. ${ }^{42}$ Lovendringen ble særlig begrunnet i hensynet til harmonisering med EU-/EØS-retten. ${ }^{43}$

Utgangspunktet er at Konkurransetilsynet må etablere konkurranseskade etter en vurdering av om konkurranseforholdene forverres etter en foretakssammenslutning. Det kan bare gripes inn dersom transaksjonen vil forårsake en kvalifisert konkurranseskade. ${ }^{44}$ EU-domstolen har formulert dette slik:

«[I]f a concentration is not the cause of the creation or strengthening of a dominant position which has a significant impact on the competitive situation on the relevant market, it must be declared compatible with the common market.» ${ }^{45}$

Kravet til årsakssammenheng innebærer at man må oppstille et hypotetisk scenario for å vurdere hvordan markedet ville utviklet seg uten transaksjonen. ${ }^{46}$ En slik tilnærming er parallell med for eksempel det erstatningsrettslige årsakskravet, der man også tar utgangspunkt i spørsmålet om hva som ville ha skjedd dersom den mulige årsaksfaktoren tenkes borte, jf. betingelseslæren. ${ }^{47}$

I foretakssammenslutningssaker vil vurderingen av de alternative scenariene - med og uten transaksjonen - være fremmadskuende, dvs. det vil dreie seg om sannsynliggjøre fremtidig utvikling. Betydningen av dette ligger imidlertid ikke på det materielle planet, men spiller en rolle først og fremst for hvilke krav som kan stilles til dokumentasjon.

Beviskravet er som hovedregel sannsynlighetsovervekt. ${ }^{48}$ I Tetra Laval sier EU-domstolen f.eks. at "Such an analysis makes it necessary to envisage various chains of cause and effect with a view to ascertaining which of them are the most likely."49

Utgangspunktet for vurderingen av scenariet uten foretakssammenslutningen er status quo, men det kan tenkes unntak fra dette. I sine retningslinjer tar EU-kommisjonen følgende utgangspunkt:

\footnotetext{
${ }^{42}$ FKF art. 2.

${ }^{43}$ Prop. 37 L (2015-2016) Endringer i krrl. (Konkurranseklagenemnda, kartellforlik mm.), s. 56 og Innst. 192 L (2015-2016), s. 10-11.

44 Ot.prp. nr. 6 (2003-04), s. 75.

${ }^{45}$ Forente saker C-68/94 og 30/95 Kali \& Salz, ECLI:EU:C:1998:148, avsn. 110. Se også sak T-342/99 Airtours, ECLI:EU:T:2002:146, avsn. 82.

${ }^{46}$ Se Kommisjonens horisontale retningslinjer, pkt. 9.

${ }^{47}$ Se departementets vedtak i klagesak over V2008-22 Opplysningen Mobil - Aspiro Søk, 17. april 2009, pkt. 7.1.

${ }^{48}$ Se f.eks. vedtak i klagesak over Konkurransetilsynets vedtak V2008-22 Opplysningen Mobil AS - Aspiro Søk AS, 17. april 2009, pkt. 7.1. Jf. nærmere Hans Petter Graver: Bevisbyrde og beviskrav i forvaltningsretten, TfR 2004 s. 465-498.

${ }^{49}$ Sak C-12/03 P (ECLI:EU:C:2005:87), prem. 43. Senere praksis fra Underretten indikerer at det i visse tilfeller vil anvendes et strengere krav enn sannsynlighetsovervekt, jf. sak T-399/16 CK Telecoms (ECLI:EU:T:2020:217), prem. 118 (påanket under sak C-376/20 P). Vi går ikke nærmere inn på spørsmål om beviskrav her.
} 
«In most cases the competitive conditions existing at the time of the merger constitute the relevant comparison for evaluating the effects of a merger. However, in some circumstances, the Commission may take into account future changes to the market that can reasonably be predicted. It may, in particular, take account of the likely entry or exit of firms if the merger did not take place when considering what constitutes the relevant comparison.» ${ }^{50}$

Tilsvarende er lagt til grunn at Konkurransetilsynet i Prosafe - Floatel. ${ }^{51}$ Poenget er at det må finnes konkrete holdepunkter for at markedet vil utvikle seg i en bestemt retning. ${ }^{52}$ Eksempelvis vurderte EUkommisjonen i $B S k y B-K i r c h P a y T V$ at sistnevntes dominerende stilling var truet pga. manglende ressurser til modernisering av infrastruktur, og at relevant sammenligningsgrunnlag derfor var fravær av dominans. ${ }^{53}$ I Nynas - Shell anså EU-kommisjonen også at stengning av infrastruktur (et raffineri) var det relevante sammenligningsgrunnlaget, altså at videre drift ikke var sannsynlig. ${ }^{54}$

På dette punktet må det nødvendigvis stilles krav til dokumentasjonen av det alternative scenariet, herunder at det som legges til grunn må etableres som mer sannsynlig enn andre potensielle utfall av konkursbehandlingen. Å velge ut ett spesifikt scenario har imidlertid bare betydning dersom det er forskjell i konkurranseskade mellom dette og andre mulige scenarier. ${ }^{55}$

\section{2 «Fallittforsvaret»}

I korte trekk går fallittforsvaret ut på at konkurranseskade ville ha oppstått uavhengig av oppkjøpet fordi foretaket som kjøpes opp ville gått konkurs og dermed forsvunnet fra markedet. ${ }^{56}$ Dette representerer imidlertid en forenkling, f.eks. fordi det kan tenkes at det i fravær av transaksjonen ville ha kommet en annen kjøper hvis oppkjøp ikke ville hindret effektiv konkurranse i samme betydelige grad, eller at konkurs faktisk er et konkurransemessig bedre alternativ fordi aktivaene kan fordeles mer gunstig mellom foretak i markedet.

På dette punktet oppstiller EU-kommisjonen tre kriterier som den anser særlig relevant under FKF; at foretaket i nær fremtid ville ha forlatt markedet pga. finansielle vanskeligheter, at foretakets aktiva i fravær av transaksjonen ville ha forlatt markedet, og at det ikke foreligger mindre konkurransebegrensende alternativer. ${ }^{57}$ Dette må også legges til grunn etter krrl., da inngrepsterskelen er harmonisert med EU-reglene. Fallittforsvaret ble anerkjent i EU i Kali \& Salz. ${ }^{58}$ I avsnitt 110 gjengir EU-domstolen EU-kommisjonens tre vilkår:

«a concentration is not the cause of the deterioration of the competitive structure if it is clear that:

the acquired undertaking would in the near future be forced out of the market if not taken over by another undertaking,

the acquiring undertaking would gain the market share of the acquired undertaking if it were forced out of the market, there is no less anticompetitive alternative purchase.»

\footnotetext{
${ }^{50}$ Horisontale retningslinjer, pkt. 9.

${ }^{51}$ V2019-22, avsn. 241 flg.

${ }^{52}$ Se Faull/Nikpay, The EU Law of Competition, 2. utg. 2014, s.668.

${ }^{53}$ Sak COMP/JV.37 (1999), opprettholdt av Retten i sak T-158/00 ARD, ECLI:EU:T:2003:246. Transaksjonen ble klarert på vilkår fordi den ville tilføre nødvendige ressurser til å opprettholde den dominerende stillingen. ${ }^{54}$ Sak M.6360.

${ }^{55}$ Se sak M.5549 EDF/ SEGEBEL, avsn. 71-7 og OFT/CCs (nå CMAs) Merger Assessment Guidelines (2010), pkt. 4.3.6.

${ }^{56}$ Se OECD Roundtable 2009: The Failing Firm Defence (www.oecd.org/competition/mergers/45810821.pdf).

${ }^{57}$ Guidelines on the assessment of horizontal mergers under the Council Regulation on the control of concentrations between undertakings, pkt. 90 .

${ }^{58}$ Forente saker C-68/94 og 30/95, Kali \& Salz, ECLI:EU:C:1998:148.
} 
EU-domstolen aksepterte disse kriteriene, og fant at EU-kommisjonen ikke hadde begått feil i anvendelsen av dem. Som utgangspunkt knytter samtlige vilkår seg til det kontrafaktiske scenarioet uten transaksjonen.

Det første vilkåret stiller krav om at foretaket ville ha forlatt markedet i nær fremtid. Dette er grunnleggende, da foretaket med fortsatt drift vil representere en faktor i konkurransen på markedet. Det andre vilkåret stiller krav om at markedsandelene til foretaket uansett måtte ha gått over til erverver. Dette vilkåret tar høyde for at konkurs kan være et bedre alternativ for konkurransen dersom markedsandelene etter konkursen fordeler seg mellom gjenværende aktører på en mer gunstig måte for konkurransen. ${ }^{59}$

På dette punktet må det imidlertid kreves at forskjellen på dette scenarioet og scenarioet med oppkjøp innebærer en betydelig begrensning i konkurransen; i motsatt fall vil ikke inngrepsvilkårene være oppfylt i forhold til alternativsituasjonen. Så langt må fallittforsvaret anses som et ordinært utslag av kravet om årsakssammenheng, og ikke som et egen forsvar mot inngrep der inngrepsvilkårene i utgangspunktet er oppfylt.

Det siste vilkåret oppstilt i Kali \& Salz innebærer at det ikke må foreligge alternative kjøpere som representerer et mer gunstig alternativ. ${ }^{60}$ Også dette vilkåret er i utgangspunktet knyttet til kravet om årsakssammenheng. Hvis et alternativt oppkjøp som er mer gunstig for konkurransen kan sannsynliggjøres som kontrafaktisk scenario, vil det åpenbart foreligge relevant årsakssammenheng (forutsatt at forskjellen mellom de to scenariene representerer en betydelig begrensning $\mathrm{i}$ konkurransen). Ut fra praktiseringen av fallittforsvaret oppstår det imidlertid to spørsmål: For det første i hvilken utstrekning et potensielt oppkjøp er relevant, herunder hvor langt konkurransemyndighetene kan gå i å påvirke det kontrafaktiske ved aktivt å søke kjøpere. For det andre om det faktisk stilles krav om at forskjellen må representere en betydelig begrensning eller «bare» at det ene er mer gunstig enn det andre. Dette blir et spørsmål om scenarioet med en alternativ kjøper kan forankres fullt ut i kravet om årsakssammenheng, eller om det må anses å stille krav til selger om at denne må velge det for konkurransen mest gunstige alternativet, samt om vedkommende kan tvinges til å selge billigere til en alternativ kjøper.

I praksis er det slik at konkurransemyndighetene tidvis har inntatt en ganske aktiv rolle mht. å finne frem til alternative kjøpere. ${ }^{61}$ Dersom en slik kjøper finnes, representerer dette et hypotetisk scenario som skiller seg fra det som kan oppstilles under en ordinær årsaksvurdering ved at konkurransemyndighetene har grepet aktivt inn i årsaksrekken. Samtidig vil prisen en slik kjøper er villig til å betale, kunne ligge langt under det opprinnelige budet. Konkurransetilsynet har gitt uttrykk for at man må akseptere alternative kjøpere med «bud ned mot likvidasjonsverdien». ${ }^{62} \mathrm{Et}$ slikt syn har etter vårt syn ikke tilstrekkelig kildemessig forankring, og går også langt dersom fallittforsvaret utelukkende skal baseres på årsaksbetraktninger. ${ }^{63}$

\footnotetext{
${ }^{59}$ For en illustrerende vurdering, se sak M.2810 Andersen, avsn. 49-52. For krrl., se Ot.prp. nr. 6 (2003-04), s. 81-82.

${ }^{60}$ Se Kommisjonens horisontale retningslinjer, pkt. 90.

${ }^{61}$ Se Kommisjonens horisontale retningslinjer, pkt. 90. Jf. for eksempel Kommisjonens vurdering av alternative kjøpere i sak M.2314 BASF/Eurodiol/Pantochim. Jf. videre Konkurransetilsynets anstrengelser for å finne alternative kjøpere til Braathens som ble kjøpt av SAS, beskrevet i tilsynets avgjørelse om ikke å gripe inn (A2001-21), pkt. 3.2.

${ }^{62}$ V2015-24 Coop - ICA, pkt. 1666, med henvisning til Evensen/Sæveraas, Konkurranseloven med kommentarer, Oslo 2009, s. 493.

${ }^{63}$ Se Erling Hjelmeng, "Årsaksvurderinger i konkurranseretten - særlig om det kontrafaktiske scenariet", TfF 2016, s. 10-45, DOI: https://doi.org/10.18261/issn.0809-9510-2016-01-02. Jf. også Ida Heldal: Fallittbedriftforsvaret ved foretakssammenslutninger, Kan det forankres i årsaksvurderinger?, masteroppgave UiO vår 2019, tilgjengelig på www.duo.uio.no.
} 
Praksis gir ikke uttrykk for en konsistent tilnærming til fallittforsvaret. For eksempel gir det liten mening å drøfte forsvaret separat fra en årsaksvurdering basert på det mest sannsynlige hypotetiske scenariet, slik Konkurransetilsynet gjorde i Coop - ICA ${ }^{64}$ Her var det allerede slått fast som ledd i årsaksvurderingen at alternativet (eller sammenligningsgrunnlaget) var et nedskalert ICA som ville samarbeide med Rema 1000 eller Coop om innkjøp. På tross av at et fallitt-scenario derfor allerede var utelukket, foretok tilsynet likevel en drøftelse av det. Hvis konkurranseanalysen derimot foretas slik at man vurderer foretakssammenslutningen opp mot status quo-scenarioet, og denne vurderingen viser en relevant konkurranseskade, vil en tilleggsvurdering av fallittforsvaret være nødvendig. I Aegean Olympic II påviste EU-kommisjonen f.eks. først konkurranseskade i forhold til status quo, og formulerte deretter problemstillingen knyttet til falittforsvaret som følger: «In the following section, the Commission will analyse the competitive situation likely to prevail if the Transaction is not implemented.» ${ }^{65}$ Hvorvidt falittforsvaret vurderes som en integrert del av årsaksvurderingen eller som et separat spørsmål etter påvist konkurranseskade ved sammenligning med status quo-situasjonen, bør uansett ikke påvirke utfallet av vurderingen.

\subsection{Alternativscenariet i en konkurssituasjon}

I et tilfelle hvor transaksjonen gjelder kjøp av aktiva fra et konkursbo, vil det ikke gi mening å legge til grunn status quo som alternativt scenario. Dette fordi en konkursbehandling ikke er en varig tilstand, og den kan ha en rekke utfall. Markedssituasjonen forut for konkursen, dvs. at foretaket som gjennomgår konkursbehandling hadde drevet videre, vil også være utelukket, nettopp på grunnlag av konkursen. At foretaket restruktureres og «gjenoppstår» i markedet vil likevel kunne være ett av flere mulige utfall av konkursbehandlingen, da forutsatt at boet driver virksomheten videre for å finne en kjøper, jf. konkursloven $\S 119 .{ }^{66}$ Vurderingen er uansett en annen enn under fallittforsvaret; der vil konkurs være ett av flere alternativer, mens konkursen for spørsmålene som drøftes her er et faktum.

En slik situasjon, der status quo er utelukket som alternativt scenario, har flere likhetstrekk med Telia/Tele2-transaksjonen i $2014 .{ }^{67}$ Her hadde Tele 2 mistet sine frekvenser i frekvensauksjonen i desember 2013, slik at en videre ordinær drift var utelukket. Akkurat som i konkurssituasjonen måtte det derfor tas stilling til hva som var den mest sannsynlige utviklingen i fravær av transaksjonen. I vedtaket uttaler Konkurransetilsynet at:

«Konkurransetilsynet er av den oppfatning at det er klare holdepunkter for at status quo ikke er det beste anslaget for mest sannsynlig markedsutvikling i fravær av

foretakssammenslutningen, og at det derfor må foretas en nærmere vurdering av hva som er mest sannsynlig markedsutvikling i alternativsituasjonen.» ${ }^{68}$

Poenget er således at man må legge til grunn det alternativet, av de ulike mulige utfallene av konkursbehandlingen, som fremstår som mest sannsynlig. For at det skal kunne gripes inn mot foretakssammenslutningen, vil det måtte foreligge en betydelig begrensning $\mathrm{i}$ konkurransen når dette scenariet sammenlignes med den aktuelle transaksjonen.

I Telia - Tele 2-transaksjonen la Konkurransetilsynet i vurderingen av alternativsituasjonen avgjørende vekt på hva som ville være økonomisk rasjonelt for kjøpsobjektet Tele2: «I denne vurderingen vil tilsynet særlig se hen til hva som fremstår som $\varnothing$ konomisk rasjonelt for Tele $2 »{ }^{69}$ Dette vil også være et naturlig utgangspunkt for vurderingen i konkurssituasjonen; spørsmålet er hvordan bostyrer vil agere for å maksimere verdiene i boet. Som nevnt vil videre drift i boets regning være ett

\footnotetext{
${ }^{64} \mathrm{~V} 2015-2$.

${ }^{65}$ Sak COMP/M.6796, avsn. 643.

${ }^{66}$ I et slikt scenario vil boet innen ganske kort tid måtte ta stilling til om det ønsker å tre inn i kontrakter, jf. f.eks. dekningsloven $\$ \S 7-10$ og 7-11.

${ }^{67}$ V2015-1.

${ }^{68}$ Ibid., pkt. 238.

${ }^{69}$ Ibid., pkt. 239.
} 
alternativ, men dette vil uansett ikke være varig. I den kontrafaktiske vurderingen vil det springende punktet være om bostyrer vil lykkes i å finne en alternativ kjøper. I fravær av konkrete holdepunkter for en slik løsning, vil det kontrafaktiske scenarioet måtte være "normalutfallet" av en konkurs, nemlig realisering av boets eiendeler.

I en slik vurdering vil det kunne etableres ulike kontrafaktiske scenarier for ulike aktiva, enten det dreier seg om aktiva som selges separat eller verdiene i boet overtas samlet av samme kjøper. Rent konseptuelt vil vurderingen av konkurranseskade ikke skille seg fra ordinære transaksjoner, forskjellen blir at status quo verken vil være situasjonen forut for konkursen eller fortsatt bobehandling, men det mest sannsynlige utfallet av bobehandlingen i fravær av transaksjonen som vurderes.

\section{Krisekarteller og fallittforetak}

Forbud mot konkurransebegrensende samarbeid følger av krrl. § 10 og EØS-avtalen art. 53. Bestemmelsene svarer til Traktaten om den Europeiske Unions Virkemåte (TEUV) art. 101, og skal i utgangspunktet tolkes og anvendes på tilsvarende måte. ${ }^{70}$ Forbudene rammer blant annet kartellvirksomhet.

Krisekartell betegner konkurranseskadelig samarbeid mellom konkurrenter, om eksempelvis priser, markeder eller kanskje helst kvantumsreduksjoner, som respons til en økonomisk krise. Krisekarteller kan være rene private initiativ eller bero på ulike former eller grader av myndighetsinvolvering. Fallittforetak kan være deltakere i krisekartell. Betegnelsene krisekartell og falittforetak har likevel ikke selvstendig rettslig betydning ved anvendelsen av forbudet mot konkurransebegrensende samarbeid.

Forbudets første ledd rammer foretakssamarbeid som har konkurranseskadelig «formål eller virkning». Formålsalternativet omfatter samarbeid som etter sin art («very nature») kan anses som konkurranseskadelig. ${ }^{71}$ Virkningsvilkåret innebærer at det må godtgjøres omstendigheter som viser at samarbeidet faktisk hindrer, innskrenker eller vrir konkurransen merkbart. ${ }^{72}$

Tolkingen av formålsvilkåret i tilknytning til krisekarteller er omhandlet av EU-domstolen i Beef Industry Development Society (BIDS). ${ }^{73}$ Bakgrunnen var en overenskomst mellom irske kjøttprodusenter om å redusere overproduksjon og -kapasitet. EU-domstolen kom til at «an agreement (...) concluded between the 10 principal beef and veal processors in Ireland, (...) requiring, among other things, a reduction of the order of $25 \%$ in processing capacity, has as its object the prevention, restriction or distortion of competition». ${ }^{74}$ Om betydningen av krisen i den irske kjøttindustrien ble det uttalt at «even supposing (...) that the parties to an agreement acted without any subjective intention of restricting competition, but with the object of remedying the effects of a crisis in their sector, such considerations are irrelevant for the purposes of applying that provision. ${ }^{75}$ EU-domstolen utelukket likevel ikke anvendelsen av unntaksbestemmelsen i forbudets tredje ledd.

Når det gjelder foretakssamarbeid som involverer fallittforetak kan det oppstå likende problemstillinger om årsakssammenheng som ved foretakssammenslutninger. Vurderingen av konkurransebegrensende virkninger fordrer også at et kontrafaktisk scenario uten samarbeidet etableres og vurderes. ${ }^{76}$ Om et eller flere av foretakene i samarbeidet sannsynlig vil forlate et marked

\footnotetext{
${ }^{70}$ Jf. EØS-rettens homogenitetsprinsipp og Ot.prp.nr.6 (2003-2004) s. 68 og 224. Se også HR-2012-1942-A, avsn. 27.

${ }^{71}$ Sak C-67/13, Cartes Bancaires, ECLI:EU:C:2014:2204, avsn. 50.

${ }^{72}$ Sak 56/65, STM, ECLI:EU:C:1966:38, sak C-67/13, Cartes Bancaires, ECLI:EU:C:2014:2204, avsn. 52.

${ }^{73}$ Sak C-209/07, Beef Industry Development Society (BIDS), ECLI:EU:C:2008:643.

${ }^{74}$ Ibid, avsn. 40.

${ }^{75}$ Ibid, avsn. 21.

${ }^{76}$ Sak 56/65, STM, ECLI:EU:C:1966:38, s. 250. Sak C-382/12 P, MasterCard, ECLI:EU:C:2014:2201, avsn. 161.
} 
på grunn av $\emptyset$ konomiske vanskeligheter i fravær av samarbeidet, kan det innvirke på om samarbeidet har kvalifisert konkurranseskadelige virkninger. ${ }^{77}$

Krrl. § 10 tredje ledd og EØS-avtalens art. 53(3) oppstiller unntaksvilkår, som blant annet krever at samarbeidet må være nødvendig for å bidra til å bedre produksjonen eller fordelingen av varene eller til å fremme den tekniske eller økonomiske utvikling og videre sikre forbrukerne en rimelig andel av fordelene som realiseres. Kapasitetsreduserende samarbeid kan unntaksvis oppfylle vilkårene, eksempelvis dersom det er tale om utfasing av ineffektiv produksjonskapasitet. ${ }^{78}$ Unntak kan for $\varnothing v$ vig også følge av det såkalte gruppefritaket for spesialiseringsavtaler. På vilkår unntar gruppefritaket overenskomster om å slutte å produsere bestemte produkter eller om å kjøpe dem av et annet foretak. ${ }^{79}$

Også problemstillinger med forbudet mot konkurransebegrensende samarbeid, ble aktualisert av utbruddet av koronaviruset våren 2020. 18. mars 2020 vedtok regjeringen forskrift om midlertidig unntak fra krrl. $\S 10$ for samarbeid i transportsektoren ${ }^{80}$ Forskriften unntar konkurransebegrensende avtaler i transportsektoren nødvendige for samfunnskritiske funksjoner i forbindelse med pandemien. Konkurransedirektøren har for $\emptyset$ vrig argumentert for at konkurransereglene i utgangspunktet bør ligge fast i krisetider. ${ }^{81}$

\section{Bøteansvar og fallittforetak}

Der et fallittforetak har overtrådt konkurranserettens forbud mot konkurransebegrensende samarbeid (krrl. § 10 og EØS-avtalen art. 53) eller misbruk av markedsdominans (krrl. § 11 og EØS-avtalen art. 54), kan det oppstå spørsmål om plassering av eventuelt bøteansvar. Konkurransetilsynet kan ilegge overtredelsesgebyr til foretak som har overtrådt konkurranselovens og EØS-avtalens forbud. ${ }^{82}$ ESAs og EU-kommisjonens bøtekompetanse ved overtredelser av EØS-avtalen art. 53 og 54 følger av forordning $1 / 2003 .^{83}$

Det er «foretak» som kan ilegges sivilrettslige bøter. Foretaksbegrepet omfatter som nevnt enhver $\emptyset$ konomisk enhet som driver $\varnothing$ konomisk virksomhet, og kan bestå av flere fysiske og juridiske personer. Det innebærer blant annet at flere selskaper i en konsernstruktur kan utgjøre ett foretak. Avgrensingen beror på om en virksomhet er relasjonelt autonom, eller underlagt en annens avgjørende strategiske kontroll. Kontroll kan blant annet følge av rettigheter til stemmeberettigede andeler eller aktiva eller av avtaler som gir innflytelse over en virksomhets besluttende organer. ${ }^{84}$

Konkurransemyndighetenes overtredelsesvedtak må rettes mot identifiserte fysiske eller juridiske personer, for at de skal kunne håndheves og bøtene inndrives. Foretaksbegrepet har innvirkning på hvilke personer vedtakene kan rettes mot. Konkurransemyndighetene kan ilegge bøter ikke bare mot et direkte overtredende rettssubjekt, men også mot kontrollerende fysiske eller juridiske personer (såkalt «morselskapsansvar»). ${ }^{85}$ EU-domstolen har likevel understreket at det ikke er tale om et objektivt ansvar. ${ }^{86}$ Grunnlaget for at bøter kan rettes mot kontrollerende rettssubjekter, foruten direkte

\footnotetext{
${ }^{77}$ Om betydningen av det kontrafaktiske for formålsvilkåret, se sak C-228/18, Budapest Bank, ECLI:EU:C:2020:265, avsn. 82-83.

${ }^{78}$ Se nærmere OECD Policy Roundtables, Crisis Cartels, 2011, s. 109 flg.

${ }^{79}$ Forskrift 20. april 2012 nr. 343 om anvendelse av krrl. § 10 tredje ledd på grupper av spesialiseringsavtaler. Regulation 1218/2010 of 14 December 2010 on the application of Article 101(3) of the Treaty on the Functioning of the European Union to certain categories of specialisation agreements.

${ }^{80}$ Forskriften gjelder for luftfartsekoren til 30. september 2020 etter forlengelse.

${ }^{81} \mathrm{https}$ ://konkurransetilsynet.no/kronikk-konkurranse-er-krisehjelp-2/

82 Jf. krrl. § 29 og EØS-krrl. § 6.

${ }^{83} \mathrm{Jf}$. ODA protokoll 4.

${ }^{84}$ Se f.eks. krrl. 17 tredje ledd og FKF art. 3(2).

${ }^{85}$ Sak C-97/08, Akzo Nobel, ECLI:EU:C:2009:536, avsn. 59. Se også ECN Plus Directive, art. 12(3).

${ }^{86}$ Sak C-97/08, Akzo Nobel, ECLI:EU:C:2009:536, avsn. 77.
} 
overtredende rettssubjekter, er nettopp den kontrollerende innflytelsen over overtrederen. ${ }^{87}$ Det innebærer at det normalt ikke er grunnlag for å holde kontrollerte rettssubjekter ansvarlige for kontrollerende rettssubjekters direkte overtredelser («datterselskapsansvar») eller ansvarlig for andre kontrollerte rettssubjekters direkte overtredelser («søsterselskapsansvar»). ${ }^{88}$

Når det gjelder fallittforetak og bøteansvar, er et spørsmål om bostyrer kan bli ansvarlig og ilegges bøter der næringsvirksomheten fortsettes for boets regning og fallittforetaket eksempelvis overtrer forbudet mot konkurranseskadelig samarbeid. Foretak som organiserer eller tilrettelegger for konkurranseskadelig samarbeid kan anses delaktige i overtredelse av dette forbudet. ${ }^{89}$ En bostyrer som inngår eller tilrettelegger for et konkurranseskadelig samarbeid på vegne av fallittforetaket, kan følgelig anses delaktig i en overtredelse av konkurransereglene og kunne ilegges bøter. Om fallittforetaket som tas under bobehandling allerede er delaktig i et konkurranseskadelig samarbeid, kan bostyrer også holdes ansvarlig om fallittforetaket viderefører samarbeidet.

I praksis kan det også oppstå spørsmål om plassering av bøteansvar der et fallittforetak har overtrådt konkurransereglene. Det konkurranserettslige bøteansvaret for tidligere kontrollerende juridiske personer kan bestå, selv om det direkte overtredende rettssubjektet ikke lenger eksisterer. Der et foretak har gjennomgått strukturelle endringer, kan dessuten foretakets suksessorer undertiden holdes ansvarlige..$^{90}$ Det innebærer at der rettssubjektet som begikk overtredelsen har opphørt å eksistere, kan et foretak som har overtatt kontrollen over overtrederens $\emptyset$ konomiske virksomhet risikere å overta bøteansvaret. For at bøteansvar skal kunne rettes mot en overtreders suksessor må formentlig overtagelsen i det minste utgjøre en foretakssammenslutning. Ved blant annet erverv av aktiva som ikke kvalifiserer til en foretakssammenslutning, kan ansvar for overtakende foretak vanskelig være aktuelt. $^{91}$

\section{Erstatningsansvar og fallittforetak}

Overtredelser av forbudene mot konkurransebegrensende samarbeid og misbruk av markedsdominans kan også medføre erstatningsansvar overfor skadelidte kunder og konkurrenter. Der et fallittforetak har overtrådt konkurransereglene, kan det også oppstå spørsmål om plassering av et eventuelt erstatningsansvar.

Som ved bøteansvar kan bostyrer potensielt bli erstatningsansvarlig der et fallittforetaks virksomhet fortsettes for boets regning, og fallittforetaket f.eks. overtrer forbudet mot konkurranseskadelig samarbeid. En bostyrer som inngår eller tilrettelegger for et konkurranseskadelig samarbeid på vegne av fallittforetaket, anses delaktig i overtredelsen. Bostyrer vil da også kunne bli solidarisk ansvarlig for et erstatningsbetingende tap en skadelidt påføres.

Der et fallittforetak har overtrådt konkurransereglene før en eventuell likvidering eller konkurs, kan det også oppstå spørsmål om kontrollerende personer eller fallittforetakets suksessorer kan holdes erstatningsansvarlige.

Tematikken er berørt av EU-domstolen i saken Vantaan kaupunki mot Skanska, NCC, Asfaltmix fra 2019. ${ }^{92}$ Bakgrunnen var at syv finske selskaper ble idømt bøter av Finlands $\emptyset$ verste forvaltningsdomstol for å ha operert et asfalt-kartell. Tre av aksjeselskapene involvert i kartellet hadde blitt kjøpt opp og senere likvidert. De overtakende selskapene Skanska Industrial Solutions Oy, NCC

\footnotetext{
${ }^{87}$ Se Generaladvokat Kokotts forslag i sak C-97/08, Akzo Nobel, ECLI:EU:C:2009:262, avsn. 39 og 47.

${ }^{88}$ Sak C-196/99, Siderúrgica, ECLI:EU:C:2003:529, avsn. 98.

${ }^{89}$ Sak C-194/14, AC-Treuhand II, ECLI:EU:C:2015:717.

${ }^{90}$ Forente saker T-259/02 etc., Raiffeisen Zentralbank Österreich, ECLI:EU:T:2006:396, avsn. 326.

${ }^{91}$ Se sak C-280/06, ETI, ECLI:EU:C:2007:775, avsnitt 42 og sak T-134/94, NMH Stahlwerke, ECLI:EU:T:1999:44, avsnitt 122 flg.

${ }^{92}$ Sak C-724/17, Vantaan kaupunki mot Skanska/NCC/Asfaltmix, ECLI:EU:C:2019:204.
} 
Industry Oy og Asfaltmix Oy ble derfor ilagt bøter. Asfaltkunden Vantaan kommune fremmet deretter erstatningskrav. De tre overtakende selskapene avviste kravene, og gjorde blant annet gjeldende at eventuelle krav skulle vært fremmet tidligere og da mot de direkte overtredende selskapene eller i likvidasjonsprosessene.

EU-domstolen kom til at EU-retten regulerer hvilke rettssubjekter som kan holdes erstatningsansvarlige for overtredelser av EU-konkurranseretten. ${ }^{93}$ Det ble vist til at traktatens forbudsbestemmelser har direkte virkning ${ }^{94}$, og til at enhver har rett til å kreve erstatning for skade forårsaket av overtredelser av forbudene. ${ }^{95}$ EU-domstolen påpekte videre at ordlyden i TEUV art. 101 utpeker «foretak» som ansvarssubjekt ${ }^{96}$, og at foretaksbegrepet viser til økonomiske enheter som kan bestå av flere fysiske og juridiske personer. ${ }^{97}$ Når det gjaldt ansvarsplassering, uttalte EU-domstolen at foretaksbegrepet ikke kan ha ulik betydning og rekkevidde i bøtesaker og erstatningssaker. ${ }^{98}$ Det ble påpekt at dersom foretak kunne unngå ansvar ved identitetsendringer, restruktureringer, transaksjoner eller liknende, ville forbudets gjennomslagskraft svekkes. ${ }^{99}$

Avgjørelsen knytter reguleringen av erstatningsrettslig ansvarsplassering til reglene om plassering av bøteansvar ved overtredelser av konkurransereglene. Avgjørelsen impliserer at skadelidte etter overtredelser av EU-konkurransereglene, kan kreve erstatning ikke bare fra direkte overtredende rettssubjekter, men også fra kontrollerende juridiske personer. Dette gjelder uavhengig av nasjonale erstatnings- og selskapsrettslige regler. Der et fallittforetak har overtrådt konkurransereglene før en eventuell konkurs eller likvidering, vil fallittforetakets eventuelle tidligere kontrollerende juridiske personer kunne holdes erstatningsansvarlige for fallittforetakets brudd på konkurransereglene. Som for bøteansvar, vil datterselskaper eller søsterselskaper av direkte overtreder i utgangspunktet ikke hefte for erstatningskrav etter EU-konkurranseretten.

Når det gjelder ansvar for suksessorer, viste EU-domstolen til at de overtakende selskapene hadde overtatt aksjene i de kartelldeltakende selskapene og deres respektive forretningsvirksomhet $\mathrm{i}$ forbindelse med likvidasjonsprosessene. ${ }^{100}$ Implikasjonen var at overtakende og overtatte virksomhet utgjorde ett og samme «foretak». De overtakende selskapene kunne derfor også holdes erstatningsansvarlige for skade forvoldt av de likviderte selskapene. ${ }^{101}$ Som for bøteansvar kan derimot et eventuelt erstatningsansvar for en suksessor vanskelig være aktuelt ved erverv av begrensede aktiva som ikke kvalifiserer til en foretakssammenslutning.

Vedrørende erstatning for brudd på EØS-avtalen art. 53 og 54, gjelder disse som norsk lov og med forrang, jf. EØS-loven $\S \S 1$ og 2. EØS-avtalen art. 53 og 54 innebærer også en rett for skadelidte til å kreve erstatning for tap påført ved atferd som innskrenker konkurransen. ${ }^{102}$ EU-domstolens avgjørelse innebærer følgelig en tilsvarende regulering av plassering av erstatningsansvar ved overtredelser av EØS-avtalens konkurranseregler.

Plassering av erstatningsansvar etter brudd på krrl. §§ 10 og 11, reguleres derimot av alminnelig norsk erstatnings- og selskapsrett. For aksjeselskapers vedkommende er aksjeeiers ansvarsbegrensning lovfestet i aksjeloven $§ 1-2$. Aksjeeier kan undertiden likevel bli erstatningsansvarlig på avtale-

\footnotetext{
${ }^{93}$ Ibid, avsn. 28.

${ }^{94}$ Ibid, avsn. 24.

95 Ibid, avsn. 26.

${ }^{96}$ Ibid, avsn. 29.

${ }^{97}$ Ibid, avsn. 37.

98 Ibid, avsn. 47.

${ }^{99}$ Ibid, avsn. 46.

${ }^{100}$ Ibid, avsn. 48.

${ }^{101}$ Ibid, avsn. 49-50.

${ }^{102}$ Sak E-10/17, Nye Kystlink mot Color Line, avsn. 71.
} 
/garantigrunnlag, culpagrunnlag ${ }^{103}$ eller medvirkningsgrunnlag. ${ }^{104}$ Høyesterett har også angitt momenter for ansvarsgjennombrudd på ulovfestet grunnlag. ${ }^{105}$ Ved overtredelser som påvirker samhandelen mellom EØS-stater, har norske domstoler likevel plikt til også å anvende EØS-avtalens konkurranseregler, jf. EØS-krrl. § 7. Det er følgelig kun ved overtredelser av krrl. §§ 10 og 11 uten samhandelspåvirkning, at ansvarsplasseringen potensielt løses ulikt EØS-konkurranseretten.

\footnotetext{
${ }^{103}$ Aksjeloven $\S 17-1(1)$.

${ }^{104}$ Aksjeloven $§ 17-1$ (2).

105 Rt. 1996 s. 672 Kongeparken, Rt. 1996 s. 742 Minnor. Se og LB-2008-133972 SAS mot Norwegian.
} 